\title{
The Effect of Varied Dietary Crude Protein Levels with Balanced Amino Acids on Performance and Egg Quality Characteristics of Layers at First Laying Phase
}

\author{
Gbemiga Oladimeji Adeyemo $^{1^{*}}$, Sulaiman Adewole Abioye ${ }^{1}$, Foluke A. Aderemi ${ }^{2}$ \\ ${ }^{1}$ Department of Animal Science, Faculty of Agriculture and Forestry, University of Ibadan, Ibadan, Nigeria; ${ }^{2}$ Department of Animal \\ Science and Fisheries Management, Faculty of Agriculture, Bowen University, Iwo, Nigeria. \\ Email: "gbemiadeyemo@yahoo.com
}

Received February $2^{\text {nd }}, 2012$; revised March $2^{\text {nd }}, 2012$; accepted March $10^{\text {th }}, 2012$

\begin{abstract}
Four diets were formulated to study the influence of varying crude protein levels on the performance, egg quality, serum and haematological characteristics at the first phase of laying cycle of sixty Bovan Nera laying birds that were randomly allotted to dietary treatments. The four experimental diets had five replicates each and three birds per replicate. Diet 1 contained $14 \%$ crude protein (CP), while diet 2 contained $15 \% \mathrm{CP}$, diets 3 and 4 contained $16 \%$ and $17 \%$ $\mathrm{CP}$ respectively. The experimental birds were fed for 10 weeks and the data collected were statistically analysed. Apparent variations recorded for all the performance characteristics such as Egg number, Hen-day production, Feed Conversion Ratio (FCR) and weight gain were significantly different $(\mathrm{p}<0.05)$. The best FCR value were recorded by birds fed $17 \%$ CP (3.45), while the highest weight gain mean value were also recorded by birds fed $17 \%$ CP value. Findings indicated a direct relationship between dietary crude protein values and performance.
\end{abstract}

Keywords: Egg Quality; First Laying Phase; Layers; Performance and Varied Crude Protein Levels

\section{Introduction}

It has been estimated that about $89.5 \mathrm{~g}$ of protein is essential for normal body functioning on a daily basis out of which a recommendation of $34 \mathrm{~g}$ of animal protein is required [1]. [2] estimated the protein intake of an average Nigerian to be approximately $54 \mathrm{~g}$ out of which $8 \mathrm{~g}$ is from animal source. As observed, the quality of protein consumption has dropped from this, a result of the deteriorating economic condition of the country. Studies have shown that animal proteins have a more balanced amino acid profile compared with plant proteins which can be used to bridge the protein deficiency gap in Nigeria's diet. Poultry production represents one of the fastest means of increasing animal protein supply of developing countries. In Nigeria, one of the greatest limitations to the expansion of the poultry industry is the high cost of feed ingredients which accounts for over $70 \%$ of the total production cost [3]. This high cost of feeding consequently affects the supply of poultry products. Thus, in order to improve the quality and supply of poultry products, it is pertinent to consider the minimum optimum level of costly ingredients in diets so as to reduce the escalating cost of poultry feed. However, poultry production in

${ }^{*}$ Corresponding author. which egg production is an important aspect is not free from constraints which limits its capacity of meeting Nigerian's demand. For every aspect of poultry production, to increase, there must be a simultaneous improvement in the feeding, breeding and management of poultry birds. Inadequate knowledge of the nutritional requirements of poultry and lack of basic information on the available feedstuffs are major factors contributing to low production and quality of poultry products especially eggs in Nigeria.

Conventional feedstuffs are expensive and the stability of their prices is unpredictable but keep increasing. The main source of protein in poultry rations are either animal proteins or plant proteins. Animal proteins include fish meal, meat and bone meal, while plant proteins include soyabean meal, groundnut cake, mustard seed meal, cotton seed meal, sesame meal, etc. The major vegetable proteins used in Nigeria are groundnut meal popularly known as groundnut cake and soybean meal. According to [4], the vegetable protein source constitutes around $30 \%$ of the total compounded poultry diet. The amino acid composition of majority of the vegetable protein sources is deficient in one or more critical amino acids like methionine, lysine etc. It is because of this that a single vegetable protein source cannot be used as a sole 
source of protein in layers ration. When protein is deficient, there is poor development in young birds and the overall vitality in adult birds is affected. When protein is excess in the diet, it undergoes de-amination which converts the protein to uric acid and is dispersed to the environment as feacal nitrogen. This feacal nitrogen, when passed out, has a harmful effect on the environment. Also, the de-amination process of the conversion of protein to uric acid requires more energy from the bird. A balanced diet of proteins should therefore be formulated for each stage of a bird's life and need according to desired growth and productivity. Since there is no single source of protein that will provide all the amino acids in the feed ration, a combination of proteins from different feedstuffs can be formulated to contain all the necessary amino acids. It is therefore necessary that birds receive enough protein both in the rearing and laying periods for optimum growth and subsequent performance. Thus this study was to determine the effect of varied dietary crude protein levels with constant amount of amino acid on the egg quality characteristic of layers.

\section{Materials and Method}

\subsection{Location of the Study}

The experiment was conducted at the Zartech research pen of the poultry section at the Teaching and Research Farm, University of Ibadan. Sixty point of lay Black Hacko birds were used for the experiment. The birds were randomly divided into 4 dietary treatments of three birds per replicate and five replicates per treatment. The pen house used for the research work was properly cleansed and disinfected. After purchase they were transferred into battery cages and given anti-stress in clean fresh water. The birds were given five weeks to adjust before the administration of the experimental feed rations. The evening before the commencement of the experiment, the birds were weighed and at the end of 10 weeks of the experiment.

\subsection{Experimental Ration}

For the experimental feeds, four dietary treatments were used. The test ingredients that were used in the dietary treatments at varied levels are soybean meal, groundnut cake, palm kennel cake (PKC) and maize while wheat offal inclusion slightly vary between treatments. The composition of the experimental diets is presented in Table 1.

\subsection{Performance Characteristics}

At the start of the experiment, the birds were weighed and this was deducted from the final weight at the end of the experiment and the differential was considered as the
Table 1. Gross composition of experiment diets containing varying crude protein content (g/100g).

\begin{tabular}{|c|c|c|c|c|}
\hline \multirow{2}{*}{ Ingredients (\%) } & $\mathrm{T}_{1}$ & $\mathrm{~T}_{2}$ & $\mathrm{~T}_{3}$ & $\mathrm{~T}_{4}$ \\
\hline & $14 \% \mathrm{CP}$ & $15 \% \mathrm{CP}$ & $16 \% \mathrm{CP}$ & $17 \% \mathrm{CP}$ \\
\hline Maize & 53.00 & 52.00 & 51.00 & 50.00 \\
\hline Wheat offal & 16.00 & 13.20 & 7.30 & 8.50 \\
\hline Soybean meal & 11.00 & 14.00 & 18.00 & 18.50 \\
\hline Palm kernel cake & 9.50 & 10.00 & 12.90 & 11.90 \\
\hline Oyster shell & 7.70 & 8.00 & 8.20 & 8.50 \\
\hline Bone meal & 2.00 & 2.00 & 2.00 & 2.00 \\
\hline Methionine & 0.10 & 0.10 & 0.10 & 0.10 \\
\hline Lysine & 0.20 & 0.20 & 0.00 & 0.00 \\
\hline Salt & 0.25 & 0.25 & 0.25 & 0.25 \\
\hline Premix ${ }^{*}$ & 0.25 & 0.25 & 0.25 & 0.25 \\
\hline Total & 100.00 & 100.00 & 100.00 & 100.00 \\
\hline \multicolumn{5}{|l|}{$\begin{array}{l}\text { Calculated } \\
\text { nutrients }\end{array}$} \\
\hline Crude protein $(\%)$ & 14.00 & 15.06 & 16.17 & 17.00 \\
\hline $\begin{array}{c}\text { Metabolisable } \\
\text { energy (Kcal/Kg) }\end{array}$ & 2566.15 & 2581.40 & 2588.10 & 2557.16 \\
\hline Methionine (\%) & 0.34 & 0.35 & 0.37 & 0.33 \\
\hline Lysine (\%) & 0.75 & 0.74 & 0.74 & 0.79 \\
\hline Calcium (\%) & 3.47 & 3.61 & 3.76 & 3.56 \\
\hline Phosphorous (\%) & 0.45 & 0.45 & 0.47 & 0.44 \\
\hline Crude fibre $(\%)$ & 4.38 & 4.32 & 4.46 & 4.64 \\
\hline
\end{tabular}

$\mathrm{CP}$-Crude Protein; ${ }^{*}$ Premix supplied per kg of diet: Vit A, 10,000 IU; Vit D, 2800 IU; Vit E, 35,000 IU; Vit K, $1900 \mathrm{mg}$; Vit B 12 mg; Riboflavin, $7000 \mathrm{mg}$; Pyridoxine, $3800 \mathrm{mg}$; Thiamine, $2200 \mathrm{mg}$; D-Pantothenic acid, $11,000 \mathrm{mg}$; Nicotinic acid, 45,000 mg; Folic acid, $1400 \mathrm{mg}$; Biotin, $113 \mathrm{mg}$; $\mathrm{Cu}, 8000 \mathrm{mg}$; Mn, 64,000 mg; Zn, 40,000 mg; Fe, 32,000 mg; Se, 160 mg; Iodine, $800 \mathrm{mg}$; Cobalt, $400 \mathrm{mg}$; Choline, 475,000 mg; Methionine, 50,000 mg; BHT, 5000 mg; Spiramycin, 5000 mg.

total weight gain. Other parameters considered were feed intake, feed conversion ratio, total weight of eggs/week, total number of eggs (total number of eggs recorded by all the 15 birds for each treatment per week), and hen day production.

\subsection{Egg Quality Analysis}

Egg-quality measurements were made on all eggs, freshly-collected, laid on two consecutive days. Egg quality was based on determination of external and internal indices, and egg components. The external indices include egg-shape index and shell thickness, and those of interior quality were albumen index, haugh unit score and yolk 
index. Collected eggs were weighed individually and their widths and lengths were measured. Then, they were broken onto a smooth level surface and the height of albumen was determined, away from the chalazae, at the two highest points on opposite sides of the yolk, using a standard tripod micrometer. The average of the two measurements of thick albumen height together with egg weight were used to compute the Haugh unit score for each individual egg as cited by Larbier \& Leclercq (1994), as follows:

$$
\text { Haugh units }=100 \log \left(\mathrm{H}+7.57-1.7 \mathrm{w}^{0.37}\right)
$$

where $\mathrm{H}$ is albumen height in millimetres $(\mathrm{mm})$ and $\mathrm{W}$ is egg weight (g).

Yolk height was also determined using the same micrometer, while yolk diameter was measured to the nearest $0.1 \mathrm{~mm}$ using a steel vernier caliper. Yolk index was calculated as yolk height $\times 100$ divided by yolk diameter. Egg-shape index was measured as egg width $\times 100$ divided by egg length. Albumen index was calculated as: [(albumen height $(\mathrm{mm}) /$ average of albumen length $(\mathrm{mm})$ and albumen width $(\mathrm{mm})] \times 100$. Shell thickness was measured using a micrometer screw gauge. Measurements were made at two corresponding positions on the equator of the eggshell and the average was recorded to the nearest $0.001 \mathrm{~mm}$.

\subsection{Statistical Analysis}

The data collected from the experiment was subjected to analysis of variance and the differences between the weekly means of egg parameters taken were tested using Duncan's multiple range test by the general linear model procedure of SAS software.

\section{Results}

\subsection{Performance Characteristics}

Effect of varied crude protein levels on performance of layers is presented in Table 2. Varying the crude protein levels significantly influenced $(\mathrm{p}<0.05)$ final weight (FW), weight gain (WG), feed conversion ratio (FCR), hen day production (HDP) and egg number (EN). The highest FW, WG, HDP and EN were obtained with birds fed $17 \%$ crude protein (treatment four). FCR was lowest at this level of crude protein content. There was no significant influence of varying crude protein on feed Intake.

\subsection{Egg Quality Analysis}

Effects of varying crude protein levels are presented in Table 3. Results show significant influence $(p<0.05)$ for egg weight (EW), yolk index (YI), albumen index (AI), shell thickness (ST) and haugh unit (HU). It was further
Table 2. Performance of laying birds fed varying crude protein levels.

\begin{tabular}{cccccc}
\hline \multirow{2}{*}{ Parameters } & $\mathrm{T}_{1}$ & $\mathrm{~T}_{2}$ & $\mathrm{~T}_{3}$ & $\mathrm{~T}_{4}$ & \\
\cline { 2 - 6 } & $14 \% \mathrm{CP}$ & $15 \% \mathrm{CP}$ & $16 \% \mathrm{CP}$ & $17 \% \mathrm{CP}$ & $\mathrm{SEM}$ \\
\hline Weight gain (gm) & $216^{\mathrm{bc}}$ & $180^{\mathrm{c}}$ & $290^{\mathrm{ab}}$ & $360^{\mathrm{a}}$ & 25.32 \\
Feed intake (gm) & 112.57 & 116.31 & 115.33 & 115.81 & 1.70 \\
FCR & $4.52^{\mathrm{a}}$ & $4.16^{\mathrm{ab}}$ & $3.79^{\mathrm{cb}}$ & $3.45^{\mathrm{c}}$ & 0.16 \\
$\begin{array}{c}\text { Hen-day } \\
\text { production (\%) }\end{array}$ & $56.95^{\mathrm{b}}$ & $61.43^{\mathrm{ab}}$ & $62.10^{\mathrm{ab}}$ & $70.48^{\mathrm{a}}$ & 2.35 \\
Egg number (\%) & $12.00^{\mathrm{b}}$ & $13.00^{\mathrm{ab}}$ & $13.00^{\mathrm{ab}}$ & $15.00^{\mathrm{a}}$ & 0.49 \\
Egg weight (g) & $44.60^{\mathrm{b}}$ & $45.72^{\mathrm{b}}$ & $49.16^{\mathrm{a}}$ & $48.26^{\mathrm{a}}$ & 0.62 \\
\hline
\end{tabular}

${ }^{a, b}$ Means with different superscript on the same row are significantly different $(\mathrm{p}<0.05)$; SEM — Standard Error of Mean; $\mathrm{CP} —$ Crude Protein.

Table 3. Egg quality parameters of laying birds fed varying crude protein levels.

\begin{tabular}{cccccc}
\hline \multirow{2}{*}{ Parameters } & $\mathrm{T}_{1}$ & $\mathrm{~T}_{2}$ & $\mathrm{~T}_{3}$ & $\mathrm{~T}_{4}$ & \\
\cline { 2 - 6 } & $14 \% \mathrm{CP}$ & $15 \% \mathrm{CP}$ & $16 \% \mathrm{CP}$ & $17 \% \mathrm{CP}$ & $\mathrm{SEM}$ \\
\hline $\begin{array}{c}\text { Shell index (\%) } \\
\text { Albumen }\end{array}$ & 89.30 & 88.07 & 87.85 & 88.33 & 0.49 \\
$\begin{array}{c}\text { index (\%) } \\
\text { Yolk index (\%) }\end{array}$ & $22.86^{\mathrm{b}}$ & $23.47^{\mathrm{b}}$ & $24.63^{\mathrm{ab}}$ & $26.47^{\mathrm{a}}$ & 0.57 \\
$\begin{array}{c}\text { Shell } \\
\text { thickness (mm) }\end{array}$ & $0.33^{\mathrm{c}}$ & $0.35^{\mathrm{b}}$ & $0.34^{\mathrm{b}}$ & $0.36^{\mathrm{a}}$ & 2.96 \\
$\begin{array}{c}\text { Haugh unit } \\
\text { Hang }\end{array}$ & $196.93^{\mathrm{b}}$ & $196.62^{\mathrm{b}}$ & $199.20^{\mathrm{ab}}$ & $201.52^{\mathrm{a}}$ & 0.84 \\
\hline
\end{tabular}

${ }^{\mathrm{a}, \mathrm{b}}$ Means with different superscript on the same row are significantly different $(\mathrm{p}<0.05)$; SEM — Standard Error of Mean; CP — Crude Protein.

observed that the highest value for yolk index and egg weights were observed at $16 \% \mathrm{CP}$ level of inclusion. The highest values for albumen index, shell thickness and haugh unit were obtained at $17 \% \mathrm{CP}$ level of inclusion.

\section{Discussion}

It has been observed by [5] that reduced crude protein level inclusion in the diet will not affect egg qualities but will only reduce the level of egg production of the laying bird. [6] reported that performance of laying hens fed 13 or $14 \%$ crude protein diets were inferior to those fed higher levels of protein, although birds on low-protein diets received all of the essential amino acids adequately. The reason for sub-optimal performance of laying hens fed low-protein amino acids supplemented diets is not clear. It is well accepted that poultry do not have specific need for protein per se but for amino acids the substance needed for body function after protein break down. Consequently, the inferior performance is not likely due to inadequate protein intake because the required amino 
acids were met. Several possibilities that exist are that the requirement for certain essential amino acids as suggested by [7] might have been underestimated. [8] opined that the requirements for isoleucine and valine as recommended [7] might not be adequate for laying hens. [9] also suggested that the [7] requirement for tryptophan and/or isoleucine might be inadequate for laying hens. Several investigators have reported that the requirements for certain essential amino acids for laying hens increase with increase in dietary level of protein. Also the amount of non-essential nitrogen in the diets containing adequate essential amino acids has not been well established. Conceivably, when the non-essential nitrogen content of a diet is limiting, the conversion of essential amino acids of the diets to the extent that they become limiting for optimal performance also exist. Variation in FCR could be attributed to differences in egg mass as resultant effects of feed intake. In addition, [10] found that chronic heat exposure significantly decreased protein digestion and reported that the feed digestibility of different components of the diets (protein, fats, starch) decreased with exposure of chickens to high temperature. The results of the present study agree with those of other studies, which indicated that reduction of dietary $\mathrm{CP}$ to $16 \%$ did not significantly affect the body mass gain of growing chicken $[11,12]$. In the same vein, [13] stated that increasing the crude protein content of the diet will increase egg production, egg weight and bird's weight but if the crude protein is included beyond the required level there will be no significant differences in egg production, egg weight and bird's weight. Results obtained from egg quality analysis however did not agree with the results of $[14,15]$, who observed that feeding a low protein diet to laying hens and broilers respectively did not significantly influence shell and internal egg quality measures and growth as these qualities were significantly influenced by the diets.

\section{Conclusion}

Based on the overall result obtained from this study, it can be deduced that the response of layers to lowered levels of dietary crude protein was lower than that of the control diet with $16 \% \mathrm{CP}$. In the same vein, the feed intake also had reducing effect on the performance of the birds. While reducing crude protein levels might impact negatively on the performance of laying birds, balancing of the amino acids and adequate supplementation will alleviate this effect.

\section{REFERENCES}

[1] FAO, "Food and Nutrition Series," Food and Agriculture Organization of the United Nations, Rome, 1984.
[2] J. A. Oluyemi and F. A. Roberts, "Poultry Production in Warm Wet Climates," Macmillian Press Ltd., London, 1979, p. 197.

[3] G. O. Adeyemo and O. G. Longe, "Effects of Graded Levels of Cottonseed Cake on Performance, Haematological and Carcass Characteristics of Broilers Fed from Day Old to 8 Weeks of Age," African Journal of Biotechnology, Vol. 6, No. 8, 2007, pp. 1064-1071.

[4] J. K. Joseph and J. Abolaji, "Effect of Replacing Maize with Graded Levels of Cooked Nigerian Mango-Seed Kernels (Mangifera indica) on the Performance, Carcass Yield and Eat Quality of Broiler Chickens," Bioresource Technology, Vol. 61, No. 1, 1997, pp. 99-102. doi:10.1016/S0960-8524(97)84705-0

[5] M. Larbier and B. Leclercq, "Nutrition and Feeding of Poultry," Nottingham University Press, Loughborough, 1994, p. 305.

[6] K. Keshavarz, "Effects of Reducing Dietary Protein, Methionine, Choline, Folic Acid and Vitamin B12 during the Late Stages of Egg Production Cycle on Performance and Eggshell Quality," Metabolism and Nutrition, Poultry Science, Vol. 82, No. 9, 2003, pp. 1407-1414.

[7] V. M. Calderson and L. S. Jensen, "The Requirement for Sulfur Amino Acid by Laying Hens as Influenced by the Protein Concentration," Poultry Science, Vol. 69, No. 6, 1990, pp. 934-944.

[8] National Research Council, "Nutrient Requirements of Poultry," 9th Edition, National Academic Press, Washington DC, 1994.

[9] L. S. Jensen, "Amino Acids and Protein for Broilers and Laying Hens," Proceedings of Maryland Nutrition Conference for Feed Manufacturers, 1991, pp. 29-36.

[10] K. Kenshavarz and M. E. Jackson, "Performance of Growing Pullets and Laying Hens Fed Low-Protein, Amino Acid-Supplemented Diets," Poultry Science, Vol. 71, No. 5, 1992, pp. 905-918.

[11] G. M. Pesti, "Impact of Dietary Amino Acid and Crude Protein Levels in Broiler Feeds on Biological Performance," The Journal of Applied Poultry Research, Vol. 18, No. 3, 2009, pp. 477-486. doi:10.3382/japr.2008-00105

[12] S. Wolde, T. Negesse and A. Melesse, "Effect of Dietary Protein Concentration on Feed Intake, Body Mass Gain and Carcass Traits of Rhode Island Red Chicken," Journal of Science and Development, Vol. 1, No. 1, 2011, pp. 53-64.

[13] Z. M. Larbier, A. M. Chagneau and P. A. Geraert, "Influence of Ambient Temperature on True Digestibility of Protein and Amino Acids of Rapeseed and Soybean Meals in Broilers," Poultry Science, Vol. 72, No. 2, 1993, pp. 298-295.

[14] O. C. Onwudike, "Effect of Different Protein Levels on the Performance of Laying Birds in a Tropical Environment," Tropical Animal Production, Vol. 8, No. 2, 1983, pp. 157-161.

[15] U.-R. María and S. Leeson, "Evaluation of Varied Dietary Crude Protein and Lysine Level at 5.7\% of Crude Protein on Productive Parameters in Broiler Chickens," Revista Científica (Maracaibo), Vol. 18, No. 2, 2008, pp. 154-159. 